\title{
The prevention of intrapartum HIV/Aids transmission from mother to child
}

L Roets, Ph.D., UFS

B Martheze, B.Soc.Sc. (Nursing), UFS

M Nel, B.Soc.Sc. (Nursing), UFS

$M$ van der Vyver, B.Soc.Sc. (Nursing), UFS

M Wilke, B.Soc.Sc. (Nursing), UFS

\section{Opsomming}

Die oordrag van MIV/VIGS vanaf die moeder na die kind is die hoof oorsaak van MIV/VIGS in kinders en kindermortaliteit. Twee-derdes van die kinders met MIV/ VIGS word gedurende die intrapartum periode geïnfekteer (Farley, 2000:1-2). Die doel van die studie was om te bepaal watter tussentredes geregistreerde vroedvroue in provinsiale obstetriese eenhede in Bloemfontein toepas om die risiko van intrapartum oordrag van MIV/VIGS vanaf die moeder na die kind te verlaag om sodoende kindermortaliteit te verlaag.

'n Beskrywende navorsingsontwerp is gevolg. Een-envyftig vroedvroue het vraelyste ingevul om te bepaal watter voorkomende praktyke hulle uitvoer.

Daar is bevind dat die meeste vroedvroue nie tussentredes implementeer om die oordrag van MIV/ VIGS van die moeder tot die kind in die intrapartum periode te verlaag nie. Dit is moontlik dat die vroedvroue nie " $n$ positiewe impak op kindermortaliteit het nie. Die afleiding word deur die navorsers gemaak dat die vroedvroue nie die tussentredes, soos genoem in die studie, implementeer nie omdat hulle nie oor die nodige kennis en vaardighede beskik nie. Uit die navorsing blyk dit dat $67 \%$ van die vroedvroue hulle opleiding tussen 1990 -2000 voltooi het. Die onvoldoende kennis kan moontlik toegeskryf word aan ' $n$ leemte in die kurrikulum van opleidingsinstansies en die gebrek aan ' $n$ resente beleid in provinsiale instansies in Bloemfontein.

Daar word aanbeveel dat al die bekostigbare tussentredes in die bestaande beleid geinkorporeer moet word.

\section{Summary}

The transmission of HIV/AIDS from mother to child is the main cause of HIV/AIDS in children and child mortality. Two-thirds of children with HIV/AIDS are infected in the intrapartum period (Farley, 2000:1-2). Midwives, through effective practices, can lower the transmission of HIV/AIDS from mother to child in the intrapartum period. The aim of the study was to determine which preventive practices registered midwives in provincial labour wards in Bloemfontein, implement to lower the risk of mother to child transmission of HIV/AIDS and in doing so to lower child mortality.

A descriptive research design was used. Fifty-one midwives completed questionnaires to determine what preventive practices are used.

The study showed that most of the midwives did not implement the interventions that could lower the chances of HIV/Aids transmission from mother to child during the intrapartum period. Midwives therefore may not have a positive impact on child mortality. The researchers concluded that midwives do not implement the interventions mentioned in the study because of a lack of knowledge and skills. Of the midwives who completed questionnaires, $67 \%$ completed their training between 1990 and 2000 . This lack of knowledge may be due to a lack in the curriculum of training institutions and of an up-to-date policy concerning the transmission of HIV/Aids in provincial institutions in Bloemfontein.

It is recommended that all affordable interventions should be incorporated in the policy.

\section{Introduction and problem statement}

The transmission of HIV/AIDS from mother to child is the main cause of HIV/AIDS in children. Two-thirds of the children with HIV/AIDS are infected in the intrapartum period (Farley, 2000:1-2).

Researchers maintain that HIV/AIDS transmission from an 
HIV-positive mother to her child is $15-20 \%$ in industrialised countries while it is $25-30 \%$ in developing countries such as South Africa. HIV/AIDS transmission is therefore higher in South Africa than in many other countries. The dilemma is that the diseases that occur during pregnancy as a result of HIV infection, occur in those parts of the world that cannot afford expensive and complex interventions, such as antiviral drugs. A global impact on HIV child mortality must therefore be made by means of simple and affordable interventions (Farley, 2000:1-2).

By means of effective interventions midwives can reduce the risk of the intrapartum transmission of HIV/AIDS from mother to child. Examples of these interventions are, among others:

- A vaginal douche with $0.25 \%$ chlorhexidine after the rupture of the membranes and during labour (Van Coeveren de Groot, 1995:13);

- Avoid artificial rupture of the membranes (Woods, 1998:18);

- No invasive foetal procedures such as skull electrodes for foetal heart monitoring and taking foetal skull pH blood specimens, must be performed (O'Grady, 1988:201-201);

- Avoid performing an episiotomy (Maier \& Maloni, 1997:157;

- Avoid deep suctioning of the airways of the neonate that could cause trauma of the mucosa (Harley, 2000:69);

- Curtail exposure of the neonate to maternal blood and amniotic fluid by rubbing the neonate dry immediately after birth and bathing it as soon as possible after birth (MacGillivray, 1996:482).

In view of the fact that the midwife is fully responsible for the intrapartum care of mother and child, it is her responsibility to pursue practices that prevent intrapartum HIV/ AIDS transmission (Regulation 2598 of 30 November 1984).

\section{Aim}

The aim of this study was to determine which preventive measures were taken by registered midwives in provincial hospitals in Bloemfontein to reduce intrapartum transmission of HIV/AIDS from mother to child and thereby to reduce child mortality.

\section{Objectives}

The objectives of the study were to:

- Identify, after a thorough analysis of the literature, the preventive measures for reducing the risk of intrapartum transmission of HIV/AIDS from mother to child;

- Identify which of the identified measures were implemented by registered midwives; and

- Make recommendations regarding the intrapartum management of HIV positive patients.

\section{Research methodology}

A descriptive design was used to acquire more information about intrapartum HIV/AIDS transmission. No manipulation of variables took place.

\section{Data collection technique}

After a thorough analysis of the literature regarding intrapartum transmission of HIV/AIDS, a structured questionnaire was used to achieve the objectives of the study. Every question was accompanied by instructions and explanations so that the respondents knew what was expected of them. An introductory letter in which the aim of the study was explained was attached to each questionnaire.

\section{Sample selection}

The researchers included all the registered midwives working in the labour wards of four provincial hospitals in Bloemfontein, therefore a sample was not taken. All the registered midwives excepting the ten who were on leave, were included. The respondents comprised the following: Hospital A, 17 midwives, Hospital B, 17 midwives, Hospital C, 17 midwives and Hospital D, 16 midwives. Sixteen of the respondents did not wish to take part in the study and were omitted. Fifty-one respondents completed the questionnaire.

\section{Course of the research}

After consent was obtained from the Ethics Committee of the Faculty of Health Sciences of the University of the Free State, as well as the management of the institutions involved, questionnaires were handed to all the respondents. Each of the four researchers was allocated a hospital where she personally handed questionnaires to the respondents and collected them immediately after they were completed.

Before completing questionnaires respondents gave written consent to the study. The researchers were available throughout to explain any unclear questions. This increased the response rate. The questionnaires were collected by the researchers directly after completion and evaluated for completeness. No faulty questionnaires (all questions were answered in the correct way) were found and therefore all the questionnaires were used. The researchers coded them personally after which they were sent to the Department of Biostatistics of the University of the Free State for processing.

All the data was collected within a fortnight after taking into account the off duty periods of the midwives and researchers.

\section{Data analysis}

Descriptive statistics, i.e. frequencies and percentages for categorical data and averages and standard deviations or medians and percentiles for continuing variables were cal- 
culated. The analysis was carried out by the Department of Biostatistics.

\section{Validity and reliability}

Validity represents the constancy of the collected information. Testing of validity focuses on three aspects, i.e. stability, ecovalence and homogeneity (Burns \& Grove, 1997:327-330).

In this study stability was difficult to ensure as the respondents did not repeat the study. However, the results would have remained unchanged if the study were to be repeated within the same time period, because the actions and views of the midwives would have remained constant. Also, there was only one version of the measuring instrument.

Content validity was ensured by determining from the review of the literature the measures that can be taken to reduce HIV transmission from mother to child. All these aspects were included and the questionnaire was submitted to domain experts for evaluation.

The reliability of a measuring instrument is determined by the degree to which it reflects the information being examined (Burns \& Grove, 1997:330-334).

Content-related reliability in this study was ensured by virtue of the fact that recently published literature such as journal articles, books and research reports were used in compiling the questionnaire. The questionnaire was also submitted for evaluation to experts on HIV/AIDS. Respondents could complete the questionnaire in English or Afrikaans.

Related measures were grouped together in the questionnaire.

\section{Pilot study}

A pilot study was conducted in the labour ward of a private hospital in Bloemfontein. The aim was to identify lack of clarity in the questionnaire, enhance the validity and reliability of the measuring instrument and to refine data colleciton and data analysis. No lack of clarity was experienced by the midwives and the instrument was left unchanged.

\section{Ethical issues}

Written consent was obtained from the Ethical Committee of the Faculty of Health Sciences of the University of the Free State and the hospitals in question.

Respondents have the right to self-determination, therefore:

- $\quad$ The range and aim of the study was explained to them and and they were able to decide whether to participate;

- $\quad$ They could withdraw from the study if they so wished;

- They were not exposed to physical or psychological harm if they chose not to take part;

- No reward was offered for participation.

Respondents have the right to privacy therefore private information, for instance a respondent's attitude to HIV/ AIDS infected patients, was handled confidentially.

Anonymity was ensured by virtue of the fact that questionnaires were numbered and nameless and respondents could not by any means be traced. Collected information was not used for any purpose other than that indicated in the research proposal. There was no discrimination in terms of race, culture or social prejudice and all respondents were therefore equitably treated. Respondents were protected and were not exposed to any physical or psychological harm or discomfort while filling in the questionnaire.

\section{Interventions that reduce HIV/Aids transmission}

Registered midwives are compelled by their scope of practice to be knowledgeable about interventions and practices that may reduce intrapartum HIV/AIDS transmission. Some of these practices will be discussed.

\section{Vaginal douche}

The vaginal passage is cleansed with a $0.25 \%$ chlorhexidine solution and $12.5 \mathrm{ml}$ chlorhexidine is added to 5 litres of water. Other solutions that may be used are nonoxynol-9 and benzalconium chloride. Nonoxynol-9 (known as a spermicide) is effective against HIV infections in vitro, but it can cause genital ulceration and vaginitis if used for long periods, thereby increasing the risk of HIV transmission. Benzalconium chloride is also effective in vitro and is welltolerated. It renders other infective agents that increase the risk of HIV transmission harmless (Van Coeveren de Groot, 1995:13; Woods, 1998:18).

A vaginal douche therefore reduces exposure of the baby to the HIV/AIDS virus.

\section{Artificial rupture of the membranes}

Membranes ruptured for more than four hours before delivery are associated with increased transmission of HIV/ AIDS from mother to child. The ruptured membranes provide a route of entry for ascending infections. Routine artificial rupture of the membranes must therefore be avoided as far as possible (Evuan, 2000:218, Brocklehurst, 1998:3). Artificial rupture of the membranes may cause haemorrhage as well as the rupture of abnormal blood vessels. The membranes should therefore be kept intact for as long as possible to avoid foetal exposure to maternal blood and vaginal secretions(Nichols \& Zwelling, 1997:911).

\section{Invasive foetal monitoring}

Invasive foetal monitoring techniques should be avoided. 
The puncture or attachment area is a direct access route for the HIV/AIDS virus (Van Coeveren de Groot, 1995:15).

\section{Performing an episiotomy}

Performing an episiotomy on a mother with HIV/AIDS must be avoided. The risk of HIV/AIDS transmission is increased as the baby comes in contact with maternal blood.

\section{Nursing care of a neonate directly after delivery Rubbing the baby dry}

Directly after delivery of the head the baby's face must be wiped with a soft cloth to rid it of all maternal secretions. The neonate's entire body must be rubbed well dry to limit exposure to maternal blood and secretions that enhance the chance of HIV/AIDS transmission (Evuan, 2000:220).

\section{Suctioning the airways}

Unnecessary suctioning of the neonate's airways must be avoided as it may cause trauma of the mucosa which will facilitate access to viral infection. Suction is unnecessary in most births. It is only necessary if there is meconium or an excessive amount of amniotic fluid in the neonate's airways that may result in other infections.

If suction is necessary the tip of the catheter may be dipped in sterile water as this facilitates access of the catheter and prevents laceration of the mucous membranes. Sterile water is also indicated to reduce the presence of micro-organisms and to help prevent infection.

Deep suction must be avoided as it can damage the mucous membrane of the neonate and offer an entry route to the HIV/AIDS virus. The nose may be suctioned with low pressure but the mouth must not be suctioned. Suction must last for less than five seconds (Nichols \& Zwelling, 1997:1138).

\section{Bathing the baby}

The neonate must be bathed as soon as possible to prevent prolonged exposure to the HIV/AIDS infected maternal secretions. The baby must not be washed with medicinal soap as it is very strong and can damage the skin, providing a direct entry route for the HIV/AIDS virus. The baby must be bathed under overhead heating to avoid hypothermia (MacGillivray, 1996:483).

\section{Administration of injections}

Vitamin $\mathrm{K}$ injections and $\mathrm{BCG}$ immunization must be administered after the baby's first bath. There must be no maternal blood or secretions on the skin as the HIV/AIDS virus can infect the baby through the puncture (Martin, 1990:321322).

\section{Breast feeding}

The World Health Organisation encourages artificial feeding for mothers who are HIV/AIDS infected in developing countries only in the following instances: if artificial feeds are readily available over a long period; if there are heating and sterilization facilities, the mother has the training and information to prepare correct feeds and can afford artificial feeds and if bottle feeding is acceptable to the mother and the community. In some communities in developing countries there is a stigma attached to artificial feeds as it is an indication that the mother is HIV positive. Because the mother feels rejected by the community she begins to breast feed her baby thereby increasing the hazard of HIV/AIDS transmission (UNAIDS, 1999:10)

If artificial feeds are incorrectly used, for instance if they are mixed with contaminated water or if the instructions are not correctly followed, severe malnutrition or fatal infective diseases may result.

Breast feeding is recommended for HIV positive babies. HIV positive children are twice as prone to diarrhoea and diarrhoea-related diseases and have an eleven times greater chance than healthy children of dying of diarrhoea. The antiviral, antibacterial and antiseptic qualities of breast milk can prevent opportunistic infections. Breast milk also has immuno-modular properties that can retard the effect of the virus on the baby's immune system (Morrison, 1998:4-6).

\section{Caesarean section versus vaginal delivery}

The risk of HIV/AIDS transmission during vaginal delivery is $20 \%$ and $14 \%$ during caesarean section. (Van Coeveren de Groot, 1995:16)

According to Brocklehurst (1998:2) studies by observation showed that risk factors for the transmission of HIV are halved by elective caesarean section. The operation must be bloodless which means that diathermy must be used for the surgical intervention.

It is within the midwife's power to reduce HIV/AIDS transmission from mother to baby in the intrapartum period in a cost-effective manner thereby making a unique contribution. Midwives must therefore be empowered with the knowledge to reduce transmission of the virus from mother to child.

\section{Findings}

\section{Period within which respondents completed their training}

Seven $(13.73 \%)$ of the respondents completed their training before 1985 , ten (19.61\%) between 1986-1990, fourteen (27.45\%) between 1991 and 1995 and twenty (39.22\%) between 1996 and 2000 . This means that $67 \%$ of the respondents completed their training in the past decade during which time HIV/AIDS played a very important role in the media, government and health services. It is, therefore, disturbing that, as will be shown later, the necessary precautions are not taken in practice. 


\section{Knowledge of the existence of policy regarding the specific management of HIV/AIDS patients}

Twenty-six $(50.98 \%)$ of the respondents knew that there was a policy regarding the specific management of HIV/ AIDS patients in their institution while $25(49.02 \%)$ did not know. The inference is that half of the registered midwives did not know about the policy or about its contents. This means that all the patients managed by $49 \%$ of the registered midwives in the intrapartum period were not given care according to the policy. Furthermore it is alarming that the existing policy does not fully define HIV/AIDS intrapartum transmission-reducing interventions.

\section{Giving an HIV positive mother a vaginal douche}

Fourteen $(27.45 \%)$ of the respondents indicated that they do give vaginal douches while $37(72.55 \%)$ stated that they do not do so. About two-thirds of the respondents therefore do not carry out preventive measures to reduce the exposure of the foetus to maternal vaginal secretions. The intrapartum transmission of HIV/AIDS is promoted in this way.

\section{Medications used for vaginal douche}

One $(7.14 \%)$ of the fourteen respondents who stated that they do give douches used saline $0.9 \%$, three $(21.43 \%)$ used $0.25 \%$ chlorhexidine and eight $(57.14 \%)$ used Savlon. Two respondents did not know which solution they used. It is clear from these figures that only three $(5.88 \%)$ of the 51 respondents used the recommended solution. Only $5.88 \%$ of the babies delivered by registered midwives in these institutions enjoy the benefit of the low cost, non-technological approach of vaginal douching of their mothers before and during delivery as recommended by Brocklehurst (1998:2)

\section{Stage at which vaginal douches are given}

The $5.88 \%$ of babies who benefited from the correct use of solutions for vaginal douches were prejudiced by virtue of the fact that $37.3 \%$ of the respondents performed vaginal douches unnecessarily. These include: eight (15.7\%) who carried out vaginal douches as a routine on admission to the labour ward and $11(21.6 \%)$ who did so postpartum; while only seven $(13.7 \%)$ gave vaginal douches after amniotomy/spontaneous rupture of the membranes and five $(9.8 \%)$ in the second stage of labour as recommended in the literature (Brocklehurst, 1998:12; Woods, 1998:18).

\section{Performance of amniotomy}

Ten respondents $(19.61 \%)$ indicated that they performed an amniotomy as a routine regardless of the HIV status of the mother. Forty-one (80.39\%) stated that they would not perform an amniotomy on HIV positive patients. According to the personal observations of the researchers and collegial discussions more than one fifth of the registered midwives perform amniotomies as a routine. This contradiction indicates that the midwives do have the appropriate knowledge but that they perform amniotomies to hasten the progress of labour at the expense of foetal wellbeing and the reduction of the transmission of the $\mathrm{HI}$ virus from mother to child.

\section{Stage at which amniotomies are performed}

Four $(40 \%)$ of the ten respondents who stated that they performed amniotomies as a routine regardless of the HIV status of the mother, did so after the cervix was five centimetres dilated and six $(60 \%)$ if labour was not progressing strictly according to the partogram. Membranes ruptured for more than four hours before delivery are associated with increased transmission of HIV/AIDS from mother to child. Ruptured membranes provide an access route to ascending infections. Routine artificial rupture of the membranes must therefore be avoided as far as possible (Evuan, 2000:218; Brocklehurst, 1998:3).

\section{The use of invasive foetal monitoring}

Two $(3.92 \%)$ of the 51 respondents would expose the foetus to maternal secretions, blood and the risk of further infection by performing invasive foetal monitoring. Both these respondents indicated that they commenced this practice as a routine on the patient's admission to the labour ward. The puncture or adherent area of the invasive procedure serves as a direct access route to the HIV virus and must therefore be avoided (Van Coeveren de Groot:1995:15). The vast majority, i.e. $96.08 \%$ of the respondents did not promote HIV transmission from mother to child because they refrained from performing invasive foetal monitoring techniques.

\section{Type of delivery of choice in singleton pregnancies of HIV positive mothers}

Sixteen $(31.37 \%)$ of the respondents believed that an elective caesarean section is the delivery of choice for singleton pregnancies of HIV positive mothers; 34 (66.67\%) believed that a normal vaginal delivery is best, while one (1.96\%) was of the opinion that a vacuum extraction should be the delivery of choice. According to Brocklehurst (1998:2) studies by observation showed that risk factors for the transmission of HIV are halved by elective caesarean section.

\section{Type of delivery of choice in multiple pregnancies of HIV positive mothers}

Thirty-one $(60.78 \%)$ of the respondents believed that an elective caesarean section is the delivery of choice in multiple pregnancies of HIV positive mothers; two (3.92\%) opted for emergency caesarean section; 15 (29.41\%) for a normal vaginal delivery; one (1.96\%) for forceps delivery and two (3.92\%) for vacuum extraction. According to the literature 


\section{FIGURE 1: When an episiotomy was performed in HIV positive patients}

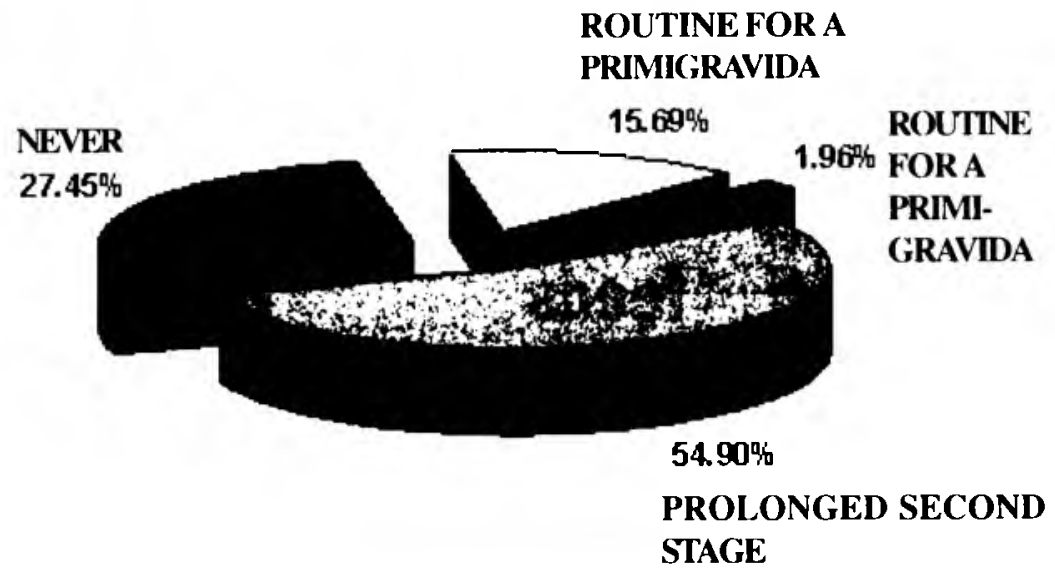

When the

neonate was

suctioned

Only nine $(17.6 \%)$ of the respondents suctioned only neonates with excessive meconium or aspirated amniotic fluid (See Figure 2). In contrast, $18 \quad(35.3 \%)$ suctioned neonates as a routine, $17(33.3 \%)$ respondents suctioned them if they did not cry immediately and six (11.8\%) did so if they were cyanotic. Five $(9.8 \%)$ respondents indicated that they never

elective caesarean section is the delivery of choice in such cases (Goedert, Duliege, Amos \& Felton., 1991:1473). Thirtyone respondents marked this as their choice of delivery, showing that they had adequate knowledge in this regard.

\section{When an episiotomy was performed on HIV positive mothers}

Fourteen $(27.45 \%)$ of the respondents answered correctly according to the literature by stating that they would never perform an episiotomy on an HIV positive mother (See Figure 1). This was in contrast to the $72.59 \%$ who would expose the foetus unnecessarily to maternal blood and consequently to increased HIV exposure by performing an episiotomy. Eight of these $(15.69 \%)$ routinely performed episiotomies on primigravidas, one $(1.96 \%)$ routinely performed them on all patients and $28(54.9 \%)$ did so in cases of a prolonged second stage. In the latter case an episiotomy can be averted by positioning and other alternatives. The mother's perineum must be wellsupported but even if lacerations should occur the blood loss is less than after an episiotomy. The baby will come in contact with less of the HIV positive blood of the mother (Maier \& Maloni, 1997:15, Pillitteri, 1999: 326).

\section{FIGURE 2: When neonates were suctioned}

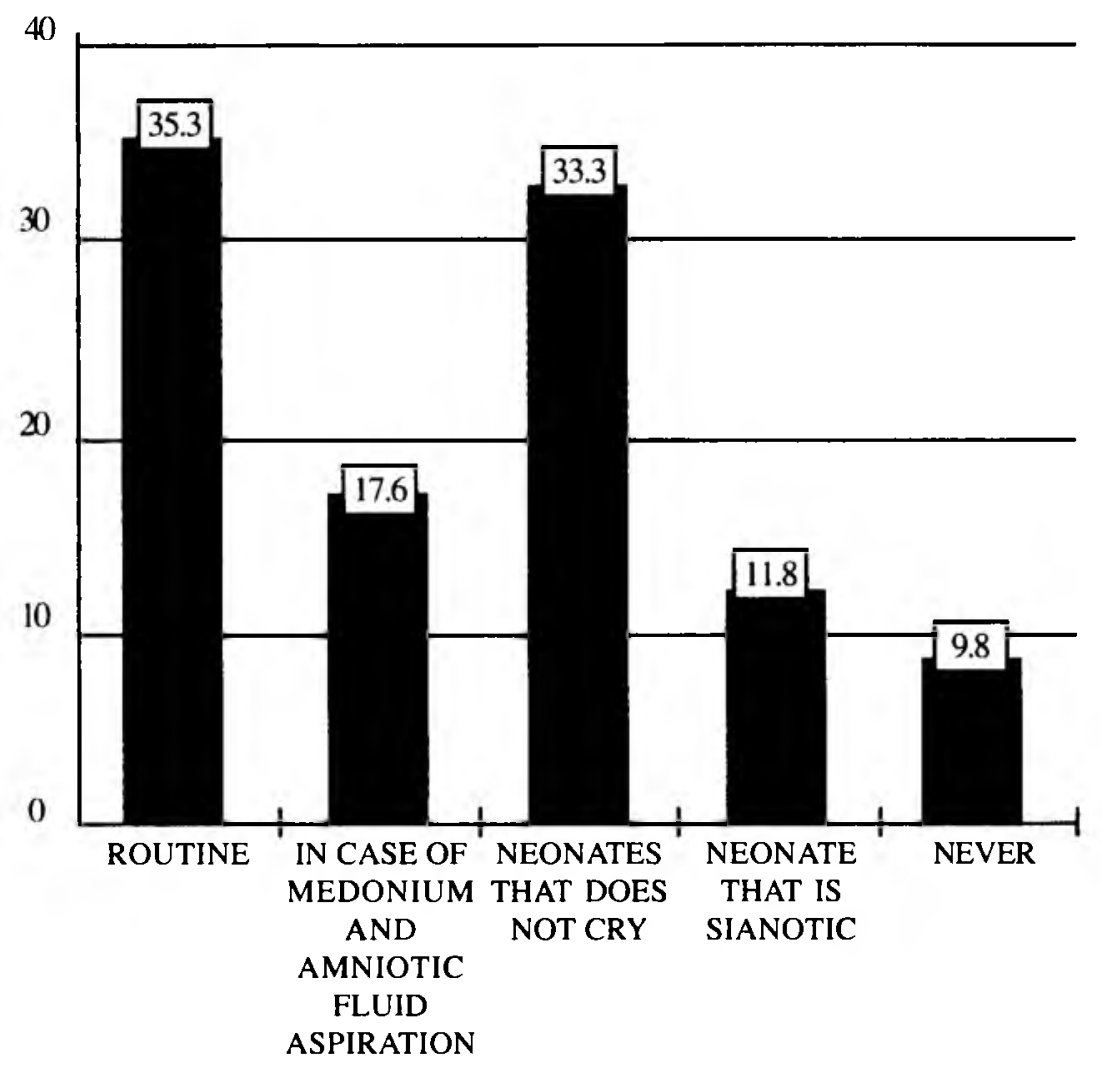




\section{When the baby was rubbed clean and dry}

Forty-nine $(96.08 \%)$ of the respondents indicated that they rub the neonates of HIV positive mothers clean and dry immediately after birth. This reduces the period of exposure to maternal secretions and blood (Evuan, 2000:220). Two respondents $(3.92 \%)$ stated that they first administer oxygen before rubbing the baby. Fory-nine of the midwives therefore have a positive impact on the reduction of HIV/ AIDS transmission from mother to child by immediately rubbing the baby clean and dry.

\section{When intramuscular Konakion was administered}

Thirty-three $(63.71 \%)$ of the respondents stated that they administered Konakion intramuscularly immediately after birth, two (3.92\%) after the baby's temperature was above $36.5^{\circ} \mathrm{C}$ and sixteen $(31.37 \%)$ after the first bath. Thirty-five $(68.83 \%)$ respondents therefore administered Konakion intramuscularly before the first bath thereby increasing the baby's exposure to HIV/AIDS as the injection provides a direct access route to maternal secretions and blood still present on its skin (Martin, 1990:321-322).

\section{When intradermal BCG was given}

Six $(11.76 \%)$ of the respondents indicated that they administered BCG intradermally directly after birth, two (3.92\%) after the baby's temperature was above $36.5^{\circ} \mathrm{C}, 40(78.43 \%)$ after the first bath and three $(5.88 \%)$ stated that they never give BCG intradermally to the baby of an HIV positive mother. Forty of the respondents administered BCG intradermally after the baby's first bath when all maternal blood and secretions have been removed from its skin thereby avoiding a direct access route to the HIV/AIDS virus (Martin, 1990:321-322).

\section{Bathing the neonate}

Twenty-eight $(56.87 \%$ ) of the respondents did not provide for the patient's HIV status and therefore contributed to child mortality by increasing HIV/AIDS infection since 21 (41.18\%) of them did not bath the baby until it maintained a temperature above $36.5^{\circ} \mathrm{C}$ and eight $(15.79 \%)$ waited six hours after birth to prevent hypothermia. Hypothermia can be avoided by using overhead heating when the baby is bathed directly after birth in order to prevent protracted exposure to maternal HIV/AIDS infected secretions and blood. Neonates must not be bathed with medicinal soap as it can damage the skin, offering a direct access route to the HIV/AIDS virus (MacGillivray, 1996:483). Twenty-two (43.14\%) of the respondents acted in terms of the literature and bathed the baby immediately after birth.

\section{Type of feeds recommended}

Twenty-one $(41.2 \%)$ of the respondents stated that they would recommend artificial feeds for neonates of HIV positive mothers. Twenty-eight $(54.9 \%)$ would recommend exclusive breast-feeding and six $(11.8 \%)$ recommended mixed feeds. Twenty-eight $(54.9 \%)$ of the midwives promoted the triple protection that breast milk offers. They enhanced mother-child bonding while having a positive impact on child mortality. Exclusive breast milk can, therefore, be recommended for the babies of HIV/AIDS infected mothers (UNAIDS, 1998:2).

\section{Factors that influence the recommended type of feeds}

Breast feeding is a lifesaver where there is no access to food and clean water. According to the World Health Organisation bottle feeding in developing countries is encouraged only if:

(1) safe water and heating and sterilization facilities are available. Only nine (17.7\%) of the midwives regarded these conditions as important for the choice of type of feeds;

(2) the mother had adequate schooling. Six (11.8\%) selected this option;

(3) the family can afford bottle feeding. Forty-eight (94.1\%) of the respondents selected this option.

Of the rest of the respondents, two (3.9\%) indicated the gravida of the mother and three $(5.9 \%)$ the birth weight of the neonate. However, these factors are not taken into account at all in decision-making about the type of feed (UNAIDS, 1999:10).

\section{Understanding of exclusive breast feeding}

Of the 51 respondents $40(78.43 \%)$ had a correct understanding of the concept and $11(21.57 \%)$ provided an incorrect definition. This means that $21.56 \%$ of the midwives did not understand the basic terminology of breast feeding and therefore could not provide HIV positive mothers with correct information about feeding their babies.

\section{Conclusions}

The findings show that most of the midwives did not apply practices or interventions to lower the transmission of HIV/ AIDS from mother to child in the intrapartum period. It is possible therefore that they did not have a positive impact on child mortality. The researchers conclude that the midwives did not implement the interventions mentioned in the study because they probably did not have the required knowledge or skills. However, there must be other reasons that were not researched. The research showed that $67 \%$ of the midwives completed their training between 1990-2000. Their inadequate knowledge may therefore be due to a deficiency in the curriculum of training institutions and the lack of a recent policy in provincial institutions in Bloemfontein.

\section{Recommendations}

- The management of the institutions involved must 
be made aware of the results of the study and the researchers will present them with a report of the research. This is necessary to motivate the managers to make available the resources to empower the registered midwives for the battle against AIDS.

The simple and affordable interventions identified by the researchers to lower the transmission rate of intrapartum HIV/AIDS from mother to child, must be incorporated in the existing policy.

- The policy must be made known to all registered midwives in the institutions. The interventions set out in the policy should be enlarged and exhibited in a prominent and attractive manner in the wards and workshops about the interventions should be conducted.

A video should be compiled incorporating all the interventions mentioned with their scientific explanations, and demonstrations of the techniques. Relevant literature used for the study by the researchers will be made available to the institutions and should be made available to all staff members. The video should be included in the inservice training programme.

A suggestion will be made to the staff of the inservice training programmes to include the video, relevant literature and the new policy as part of the induction programme of the institutions.

Despite the fact that $67 \%$ of the respondents of this study completed their training in the past ten years, deficiencies were found in their interventions. For this reason the findings of the research should be made known to all training schools in the country for inclusion in their midwifery curricula.

The study should be repeated after two years to ascertain whether the recommendations of the researchers made an impact.

The research will be presented at the research forum of the medical faculty of the University of the Free State to expose all the members of the multidisciplinary team to the findings.

- In private practice babies are delivered by doctors and therefore the researchers recommend that a copy of the research report be handed to the Dean of the Faculty of Health Sciences of the University of the Free State in order that the interventions may be included in the curriculum of the medical school.

\section{Synopsis}

Seventy thousand children are infected with the HIV/AIDS virus every year in South Africa (McGeary, 2001:53). Registered midwives can, therefore, make a great impact on child mortality as two-thirds of these children are infected in the intrapartum period (Farley, 2000:1). At present the media are giving great prominence to the use of antiviral drugs for reducing the rate of transmission of HIV/AIDS from mother to child. In view of the economic status of the country there must be a shift in emphasis from expensive complex interventions to simple and affordable practices as discussed in the study. Midwives who are empowered with the appropriate knowledge and skills are South Africa's first line of defence.

\section{Bibliography}

BROCKLEHURST, P 1998: Interventions aimed at decreasing the risk of mother-to-child transmission of HIV infection. WHO Reproductive Health Library. (2):1-10.

BURNS, N \& GROVE, S 1997: The practice of nursing research conduct, critique and utelization. Philadelphia: Sanders.

COUTSOUDIS, A, PILLAY, K, SPOONER, E, KUHN, L \& COOVADIA, HM 1999: Influence of infant-feeding patterns on early mother-to-child transmission of HIV-1 in Durban, South Africa: a prospective cohort study. Lancet. 354(8):471-476.

EVUAN, C. 2000. Primary AIDS care. Johannesburg: Jacana Education.

FARLEY, T 2000: Summary of new Recommendations on the use of ARV in preventing MTCT of HIV. www.unaids.crg/publications/documents/mtct/recomm arv e.doc

GOEDERT, JJ, DULIEGE, A, AMOS, CI \& FELTON, S 1991: High risk of HIV-1 infection for first-born twins. The Lancet, 338(8781):1471-1475.

HARLEY, B. 2000. Mother-to-child transmission and family planning in $\mathrm{HIV}$-infected women. Update. 4(7):68-70.

MCGEARY, J 2001: Death stalks a continent. Time. 157(6):46-54.

MacGILLIVRAY, TP 1996: A newborn's first bath: When? JOGNN 25(6):481-487.

MAIER, JS \& MALONI, JA 1997: Nurse advocacy for selective versus routine episiotomy. JOGNN Principles \& Practice. 26(2):155-161.

MANDELBROT,L,MAYAUX,MJ,BONGIN,A, BERREBI, A,MOUIXOUB-JEANPETIT, Y, BENIFLA,J \& BLANCHE, S 1996: Obstetric factors and mother-to-child transmission of human immunodeficiency virus type 1: The French perinatal cohorts. American Journal of Obstetric Gynecology. 175:661-667.

MARTIN, EJ 1990: Intrapartum management modules: A perinatal education program. Baltimore:Williams \& Wilkens. 
McGEARY, J 2001: Death stalks a content. Time. 157 (6): 46-54.

MORRISON, $P$ 1998: Breastmilk feeding: Is this a safe alternative to breastfeeding for the HIV+ mother? The Gauteng chapter of La Leche League South Africa $7^{\text {th }}$ area conference. Johannesburg.

NICHOLS, FH \& ZWELLING, E 1997: Maternal-newborn nursing: Theory and practice. Philadelphia: W.B. Saunders Co.

O'GRADY, JP 1988: Modern instrumental delivery. Baltimore: Williams \& Wilkens. Suid-Afrikaanse Raad op Verpleging. Regulasie 2598 van November 1984, soos gewysig.

PILLITTERI, A 1999: Maternal and Child Health Nursing. Baltimore. Philadelphia.

UNAIDS: Technical update 1998: Mother-to-child transmission of HIV. www.unaids.org

UNAIDS 1999: Prevension of HIV transmission from mother to child: Strategic options. www.unaids.org.

VANCOEVEREN DE GROOT, HA 1995: The frequency of vertical (mother-to-child) transmission of HIV infection. COPE: Journal of the Midwife Obstetric Units Cape Town. 9(1):12-19.

WOODS, DI 1998: Vertical transmission of HIV infection. COPE: Joumal of the Midwife Obstetric Units Cape. 12(1):18 